Nevşehir Bilim ve Teknoloji Dergisi Cilt 4(1) 69-80 2015

DOI: 10.17100/nevbiltek.210947

URL: http://dx.doi.org/10.17100/nevbiltek.210947

\title{
A Solution Adaptive Cartesian Grid Based Euler Solution for Compressible Flow Around BOEING TR-1322 Multi-element Airfoil
}

\author{
Emre KARA ${ }^{1, *}$, Ahmet İhsan KUTLAR ${ }^{1}$, Mehmet Halûk AKSEL ${ }^{2}$ \\ ${ }^{1}$ University of Gaziantep, Mechanical Engineering Department, 27310, Gaziantep, Turkey \\ ${ }^{2}$ Middle East Technical University, Mechanical Engineering Department, 06800, Ankara, Turkey \\ Abstract
}

Cartesian grids constitute a special branch in unstructured grid technology. They use specially designed algorithms to generate automatic grids for complex geometries and to simulate flows around such geometries regardless of the body shape and number of bodies. Cartesian grids are generated by constructing a quadtree based data structure for the purpose of connecting the Cartesian cells to each other. A "hands-off”, Cartesian grid generator based Euler solution called GeULER is implemented in object-oriented FORTRAN programming language. In this study, implementations of generated two-dimensional adaptive refinement/coarsening scheme codes are appended to the developed compressible flow solver by using special Cartesian-based algorithms, namely cut-cell adaptation and curvature adaptation around BOEING TR-1322 multi-element airfoil. A subsonic flow at free stream Mach number of 0.11 around the airfoil is tested to predict pressure distributions around it and Mach contours of the flow are depicted by using the developed GeULER code.

Keywords: Cartesian grid generation, object-oriented FORTRAN programming, solution adaptation, Euler solution

\section{BOEING TR-1322 Çoklu-elemanlı Kanat Profili Çevresinde Sıkıştırılabilir Akış için Çözüm Uyarlamalı Kartezyen Ă̆ Temelli Euler Çözümü}

$\ddot{O} z$

Kartezyen ağlar yapısal olmayan ağ teknolojisi içinde özel bir dal oluşturmaktadır. Karmaşık geometriler için otomatik ağ oluşturmak ve bu gibi geometriler etrafında akışın gövde şeklinden ve sayısından bağımsız şekilde benzetim kurmak için özellikle tasarlanmış algoritmalar kullanırlar. Kartezyen ağlar, Kartezyen hücrelerinin birbirlerine bağlanmalarını sağlamak için oluşturulan dörtlü ağaç temelli veri yapısı kullanarak üretilmiştir. GeULER isimli, kullanıcı müdahalesine gerek olmayan, nesne tabanlı FORTRAN programlama dilinde Kartezyen ağ üreticisi temelli Euler çözümü uygulanmıştır. Bu çalışmada, geliştirilen sıkıştırılabilir akış çözücüsüne, BOEING TR-1322 çoklu-elemanlı kanat profili çevresinde kesik hücre uyarlaması ve eğri uyarlaması gibi özel Kartezyen temelli algoritmalar kullanılarak iki-boyutlu uyarlanabilir geliştirme/genişleme şema kodları ilave edilmiştir. Kanat profili üzerinde, 0.11 serbest akım Mach sayısında, ses altı akışta kanat çevresindeki basınç dağılımının tahmini için test edilmiş ve geliştirilen GeULER kodu kullanılarak akışın Mach konturları tasvir edilmiştir.

Anahtar Kelimeler: Kartezyen ağ üretimi, nesne tabanlı FORTRAN programlama, çözüm uyarlaması, Euler çözümü

\footnotetext{
*e-mail: emrekara@gantep.edu.tr
} 


\section{Introduction}

The multi-element BOEING Model TR-1332 airfoil test case is selected for this study, because aircraft industry mainly focuses its attention on the multi-element airfoils and their improvements [1]. The flow field contains more detailed and more complex flow phenomena such as wakes, mixing layers in comparison with single element airfoil. Unfortunately, only a few multi-element airfoils such as the current test case BOEING Model TR-1332, British L1T2 and 30P30N airfoils are available to public [2]. The selected test case has very low Reynolds number that can be approved as Euler solution but has also very low Mach number, critically high viscous interaction. At the end of this study, it will be seen that current Euler solver is capable of being employed at the bound of incompressible flow. The main reason for selecting this study is that corresponding airfoil is a four element, highly challenging construction. Although the airfoil is suggested as a CFD validation study in the AGARD Advisory Report [3], it is not studied as a CFD validation test case in literature till current study so that verification cannot be run for BOEING Model TR-1332 multi-element airfoil.

As shown in Figure 1.a, BOEING Model TR-1332 airfoil has four elements: a slat, a main foil and double-slotted flap. The surface coordinates and experimental data for the test case are obtained from Case A-13 in the AGARD Advisory Report as shown in Figure 1.b [3]. This case is actually a turbulent flow but the current treatment concentrates only on the solution of pressure distribution around the airfoil.

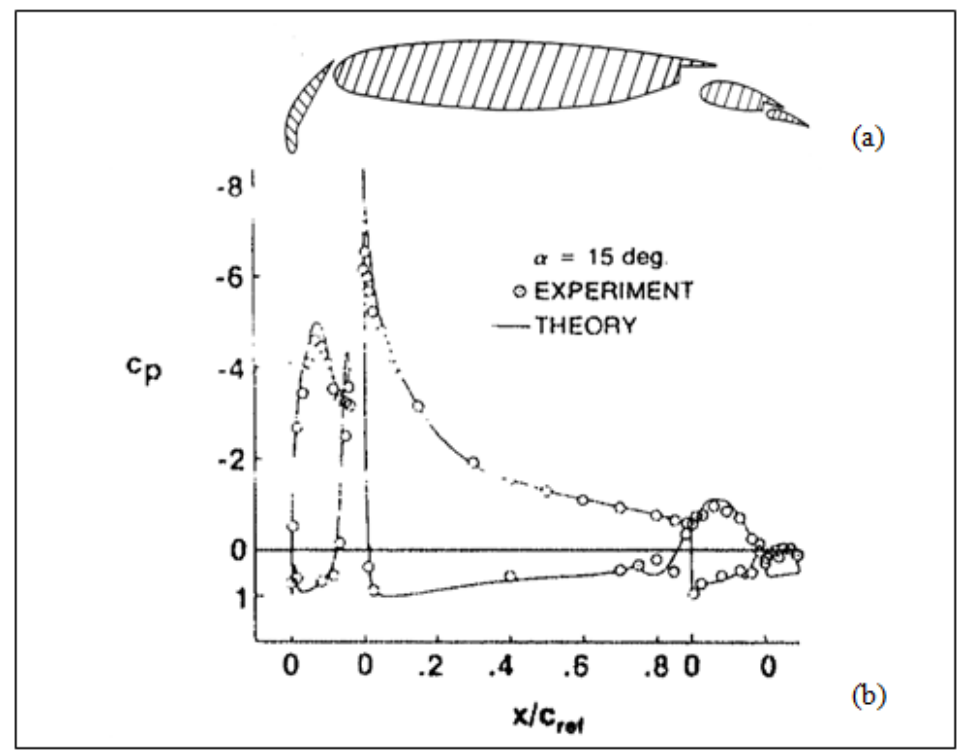

Figure 1. (a) Geometry of BOEING model TR-1332, (b) pressure coefficient distribution on BOEING model TR-1332 [3]

A quadtree Cartesian grid generator is constructed using special Cartesian algorithms and objectoriented programming of FORTRAN [4]. A Cartesian grid based, finite volume solver is developed to produce accurate solutions of inviscid flow around two-dimensional airfoil. The computational domain around the multi-element airfoil is first discretized into a set of elemental cells. Box adaptation around the four-element airfoil geometry with 2 cycles of cut-cell adaptation and 3 cycles of curvature adaptation is shown using the developed GeULER (cartesian-Grid-generator-with-eULER-solver) code in Figure 2. Details of these adaptation types can be found in author's previous study [5]. 

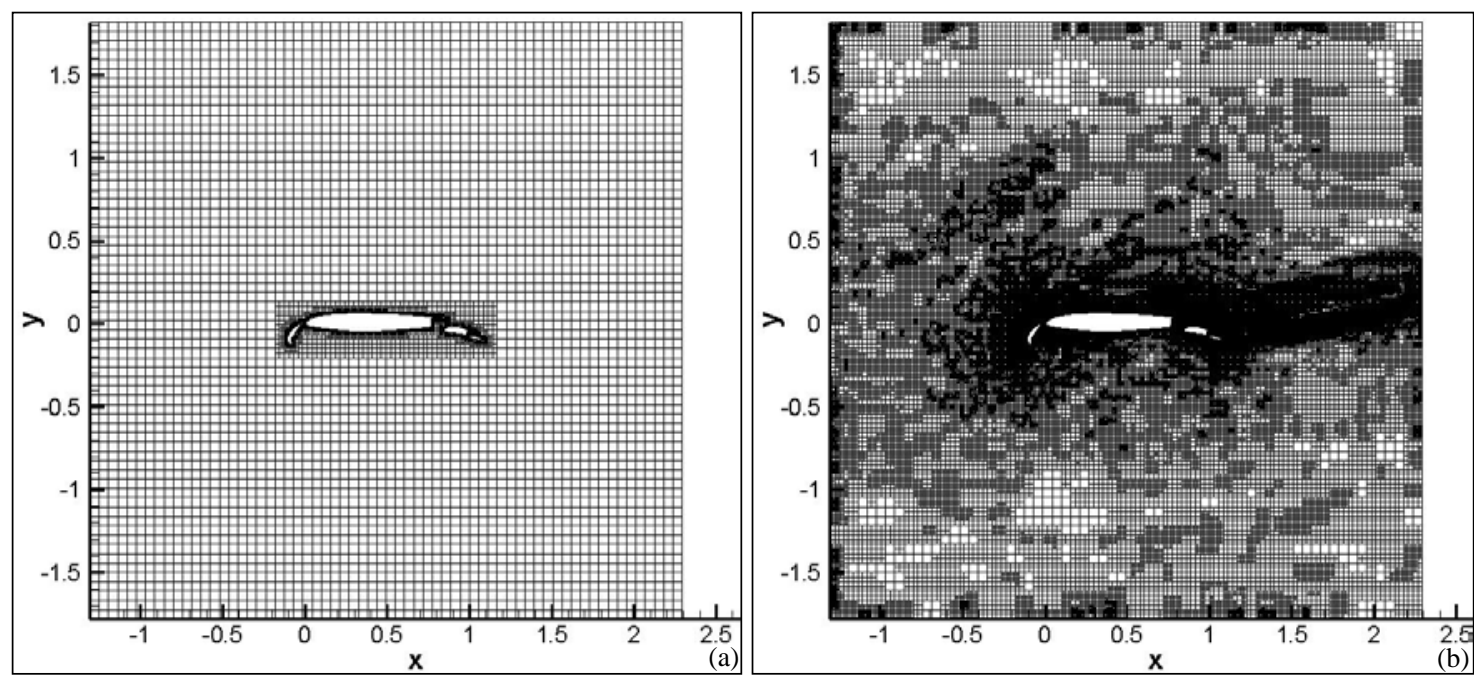

Figure 2. (a) Box adapted (b) Solution adapted grid around BOEING Model TR-1332 airfoil by GeULER code .

\section{Materials and Methods}

\subsection{Governing equations}

In this section, the integral forms of two-dimensional Euler equations are presented. Considering an arbitrary control cell the conservative integral form of Euler equations is generated using Gauss divergence theorem as follows:

$$
\frac{\partial}{\partial t} \int_{A} \boldsymbol{Q} \mathrm{d} A+\int_{S}(\mathbf{F} \cdot \mathbf{n}) \mathrm{d} S=0
$$

where $A$ is the cell area, $\mathbf{F}$ is the inviscid flux vector, $\mathbf{n}$ is the normal vector, $S$ is perimeter of the contour surrounding $A$. $\mathbf{Q}$ represents the vector of any conserved variable such as density, $\rho, \mathrm{x}$ - and $\mathrm{y}$-velocity components, $u$ and $v$, respectively or total energy, $E$. A non-dimensionalisation procedure is employed (i) to simplify equations described above, (ii) to appreciate the dominant flow physics and more importantly, (iii) to prevent lack of equalities in scale of dependent variables, hence, the numerical errors resulting from them [6].

\subsection{Spatial discretization}

Flow variables computed from Euler equations are stored at the centroids of each cell assuming that the variables of each cell do not vary throughout the cell. Semi-discrete form of Eq. (1) can be written as the sum of the fluxes through each cell as follows:

$$
A \frac{\partial \boldsymbol{Q}}{\partial t}+\sum_{\mathrm{f}=1}^{4}(\mathbf{F} \cdot \mathbf{n}) \Delta S=0
$$

It is assumed that convective fluxes are constant on surfaces and time stepping of the conserved variables on faces is inherited from the one calculated on centroid of the area. The residuals, Res, of each cell can be defined in the following equation:

$$
\frac{\partial \boldsymbol{Q}}{\partial t}=-\frac{1}{A} \operatorname{Res}(\boldsymbol{Q})
$$

\subsection{Temporal discretization}


Following spatial discretization, the time derivatives of the conserved variables are now discretized to obtain almost-zero residuals by iteration. Left hand side of Eq. (3) is discretized in time $(\Delta t)$ as the finite difference of conserved variable between step number $m+1$ and step number $m$ :

$$
\frac{\partial \boldsymbol{Q}}{\partial t}=\frac{\boldsymbol{Q}^{m+1}-\boldsymbol{Q}^{m}}{\Delta t}
$$

In the solver, explicit time stepping scheme is used and Taylor series expansion for this second order $O\left(\operatorname{Res}^{2}\right)$ scheme is given by neglecting higher order terms:

$$
\operatorname{Res}\left(\boldsymbol{Q}^{m+1}\right)=\operatorname{Res}\left(\boldsymbol{Q}^{m}\right)+\frac{\partial \operatorname{Res}\left(\boldsymbol{Q}^{m}\right)}{\partial \boldsymbol{Q}}\left(\boldsymbol{Q}^{m+1}-\boldsymbol{Q}^{m}\right)+O\left(\operatorname{Res}^{2}\right)
$$

In the integration of the flow solver, n-stage time stepping scheme using Runge Kutta (RK) method with the first order accuracy is used, which is given as [7]:

$$
\begin{gathered}
\boldsymbol{Q}^{(0)}=\boldsymbol{Q}^{m} ; \boldsymbol{Q}^{(1)}=\boldsymbol{Q}^{(0)}-C F L \frac{\alpha_{1} \Delta t}{A} \operatorname{Res}\left(\boldsymbol{Q}^{(0)}\right) ; \boldsymbol{Q}^{(2)}=\boldsymbol{Q}^{(0)}-C F L \frac{\alpha_{2} \Delta t}{A} \operatorname{Res}\left(\boldsymbol{Q}^{(1)}\right) \\
\ldots \\
\boldsymbol{Q}^{(m+1)}=\boldsymbol{Q}^{(n)}=\boldsymbol{Q}^{(0)}-C F L \frac{\alpha_{n} \Delta t}{A} \operatorname{Res}\left(\boldsymbol{Q}^{(n-1)}\right)
\end{gathered}
$$

where $n$ is the RK stage number, CFL is the Courant-Friedrichs-Levy number and $\alpha$ 's are the stage coefficients.

\subsection{CFL cut-back procedure}

Coirier and Powell proposed a cut-back procedure for CFL number used in time stepping scheme to avoid getting unphysical classification of the initial state. CFL cut-back procedure is achieved by the following equations [8]:

$$
C F L_{c b}=\min (C F L, \widehat{C F} L) ; \widehat{C F} L=\frac{\epsilon_{t}}{\max \left(\epsilon_{p}, \epsilon_{\rho}\right)}
$$

where $\epsilon_{\mathrm{t}}$ is a scalar threshold value that is suggested to have a value in the order of $10^{-2} . \epsilon_{p}$ and $\epsilon_{\rho}$ are change of the normalized pressure and density through a computational cell, respectively. $\mathrm{CFL}_{\mathrm{cb}}$ is the updated CFL number after the procedure. This step is not obligatory in three-dimensional computations but it is necessary in two-dimensional ones and needed for only 10-20 prior iterations.

\subsection{Solution adaptation}

During execution of the flow solver, Cartesian grid based structure makes it easier to locally refine or coarsen grids on the critical regions such as shock-based discontinuities, stagnation points, shear layers, etc. This phenomenon is called as solution adaptation which increases the accuracy of the results. Two characteristic lengths, $\varsigma$, of the control cell are used to gain possession of changing conservative variables from one cell to its neighboring cells by:

$$
\zeta_{D, x}=|\nabla \bullet u| A^{0.5} ; \zeta_{D, y}=|\nabla \bullet v| A^{0.5} ; \varsigma_{C, x}=|\nabla \times u| A^{0.5} ; \varsigma_{C, y}=|\nabla \times v| A^{0.5}
$$

where subscripts ${ }_{D}$ and $C_{C}$ stand for divergence and curl of the velocity vectors, respectively. The standard deviation of these two characteristic lengths, are calculated for entire solution domain by:

$$
\sigma_{D}=\frac{1}{N} \sum_{i=1}^{N} \varsigma_{D, x}{ }^{2}+\varsigma_{D, y}{ }^{2} ; \quad \sigma_{C}=\frac{1}{N} \sum_{i=1}^{N} \varsigma_{C, x^{2}}+\varsigma_{C, y}{ }^{2}
$$


where $\mathrm{N}$ is the total number of solution domain cells. Cells are flagged for refinement or coarsening using the threshold values $t_{r}$ and $t_{c}$ for refinement and coarsening respectively, following the criteria below:

$$
\begin{aligned}
& \text { if }\left(\varsigma_{D, x}+\varsigma_{D, y}>t_{r} \sigma_{D}\right) \text { and }\left(\varsigma_{C, x}+\varsigma_{C, y}>t_{r} \sigma_{C}\right) \text { refine } \\
& \text { if }\left(\varsigma_{D, x}+\varsigma_{D, y}<t_{c} \sigma_{D}\right) \text { and }\left(\varsigma_{C, x}+\varsigma_{C, y}<t_{c} \sigma_{C}\right) \text { coarsen }
\end{aligned}
$$

$t_{r}$ is taken as 1 and $t_{c}$ is taken as 0.1 [9].

\section{Results}

Employing a saw-tooth cycle, the convergence has taken place in seven multi-grid cycle numbers (Figure 3). Validation of the numerical results is accomplished by comparison with the experimentally obtained data from the experimental study around BOEING Model TR-1332 airfoil [3].
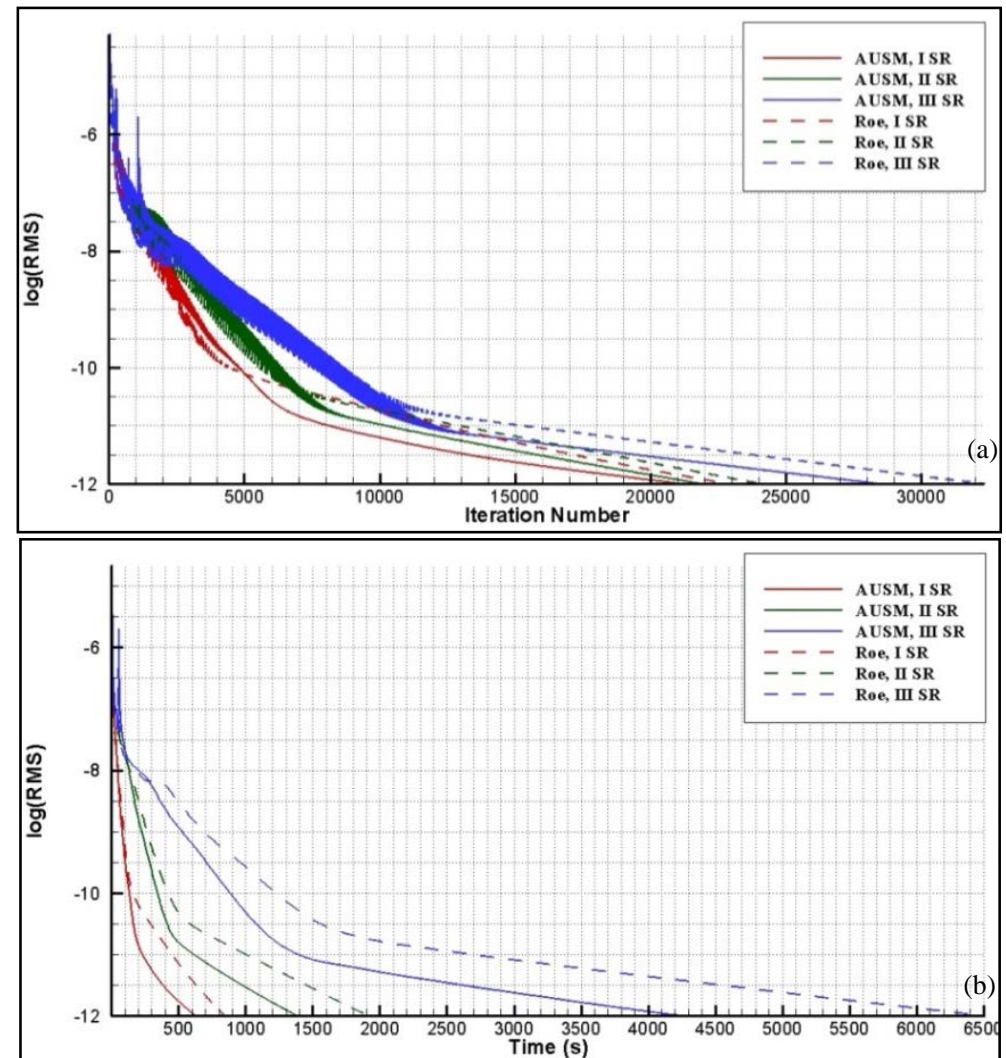

Figure 3. Subsonic test case of BOEING Model TR-1332 airfoil: (a) Convergence history and (b) residuals versus CPU time.

Employing the solution adaptation techniques, pressure coefficient distribution, $c_{p}$, around the model obtained by using Liou’s Advection Upstream Splitting Method (AUSM) and Roe’s approximate Riemann solver and Mach contours of the flow are depicted in Figures 4, 5 and 6, respectively, by using the developed GeULER code [6]. It should be noted that the difference between the experimental pressure lines and the results of GeULER due to the negligence of viscous terms and Cartesian grid solutions are known to suffer from staircase phenomenon [10]. 
Kara E., Kutlar Aí., Aksel MH.
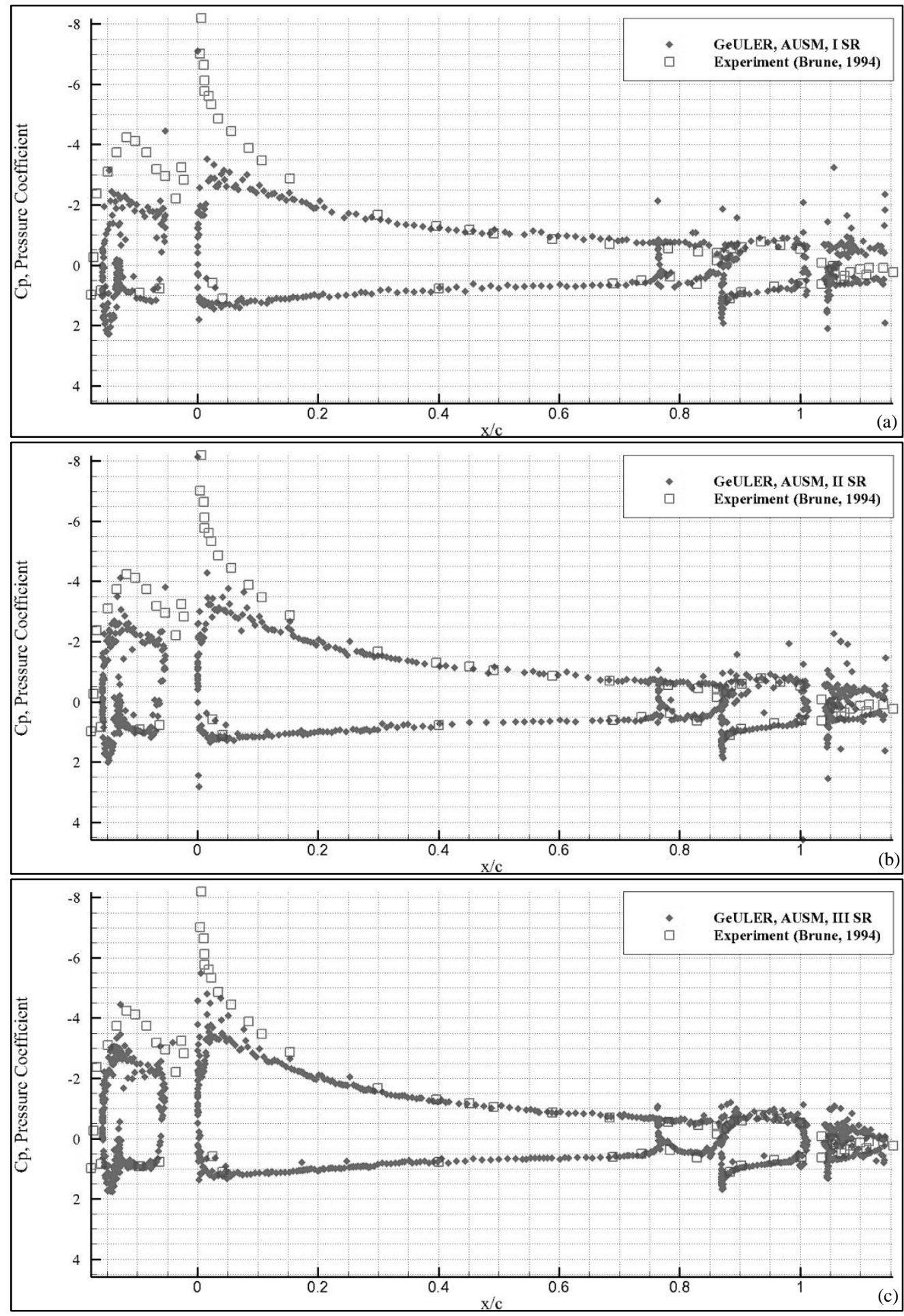

Figure 4. GeULER results of pressure coefficient $\left(c_{p}\right)$ distributions along the surface of four element BOEING Model TR-1332 airfoil by using AUSM with (a) one solution refinement (SR) (b) two SR, (c) three SR; $M_{\infty}=0.11, \theta=15.0^{\circ}$.

In both GeULER solutions of AUSM and Roe's approximate Riemann solutions, as seen, in respective order, in Figures 4 and 5 while the solution refinement level increases, $c_{p}$ distributions are seen to approach near to the experimental data. GeULER simulations of Roe's approximate Riemann solver solution have better agreement with the experimental data than AUSM solutions, except for the slat of the multi-element airfoil. 

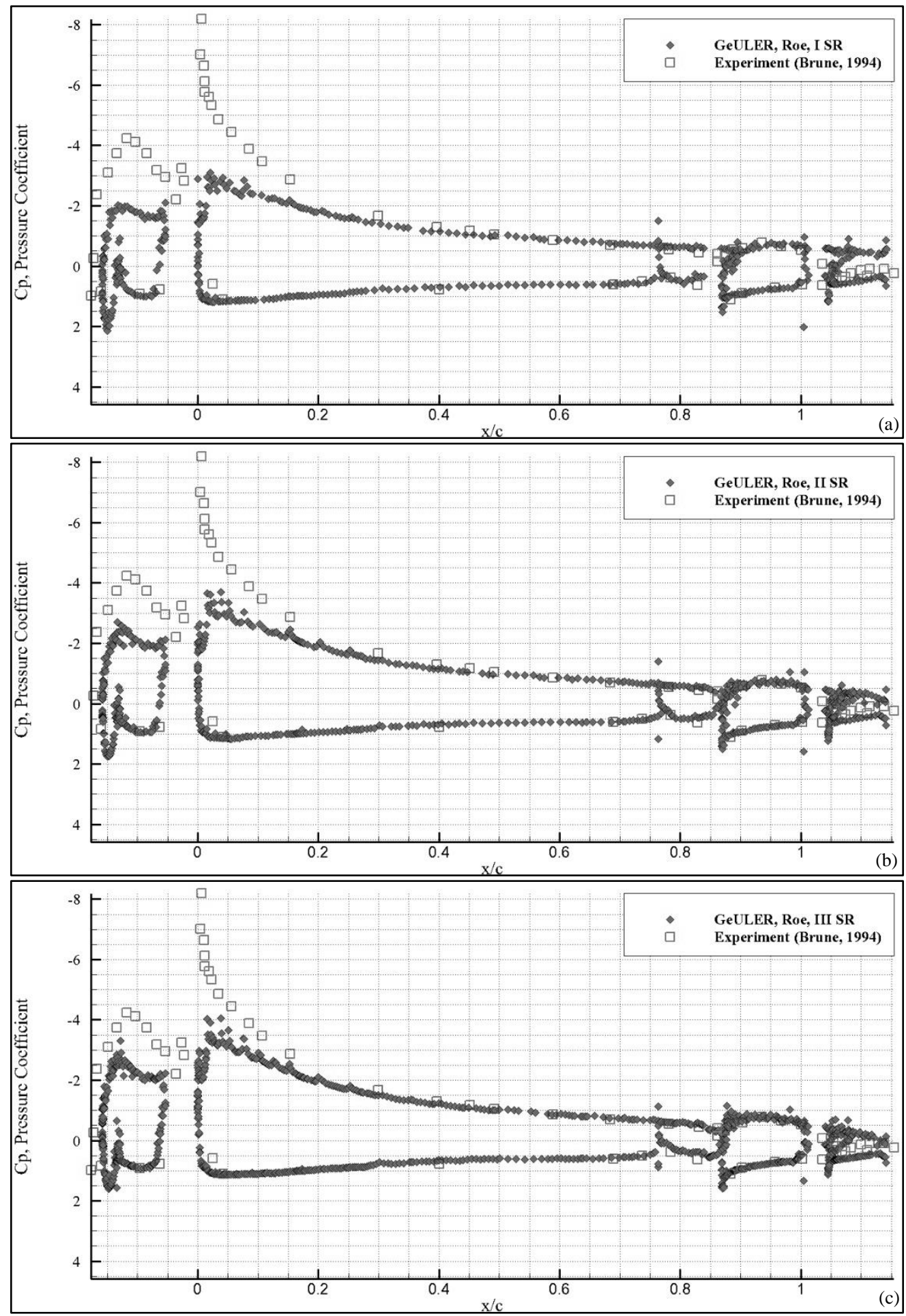

Figure 5. GeULER results of pressure coefficient $\left(c_{p}\right)$ distributions along the surface of four element BOEING Model TR-1332 airfoil by using Roe's Riemann solver with (a) one solution refinement (SR) (b) two SR, (c) three SR; $M_{\infty}=0.11, \theta=15.0^{\circ}$. 
Kara E., Kutlar Aí., Aksel MH.

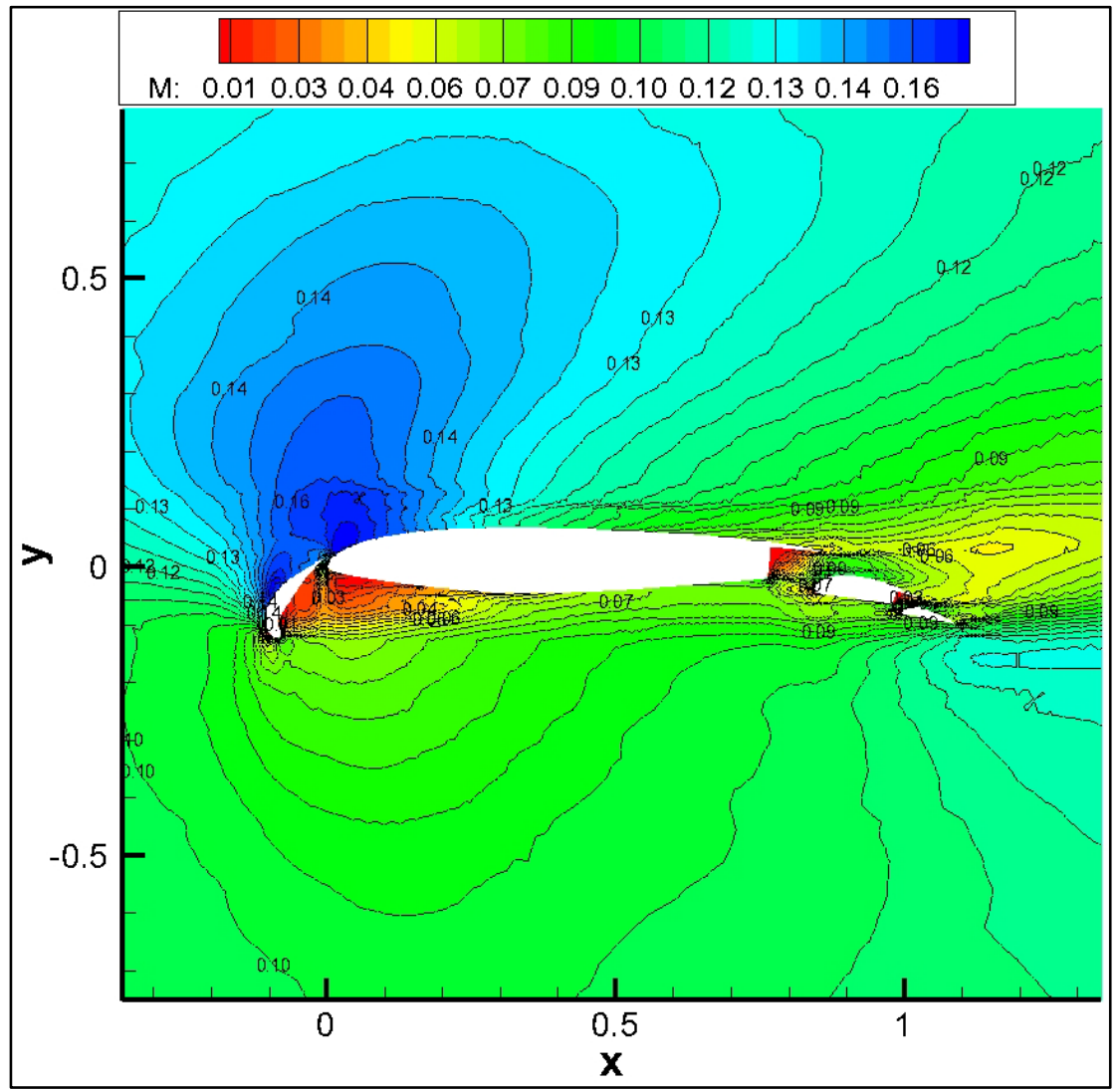

Figure 6. GeULER results of Mach number contours around BOEING Model TR-1332 by AUSM with one SR.

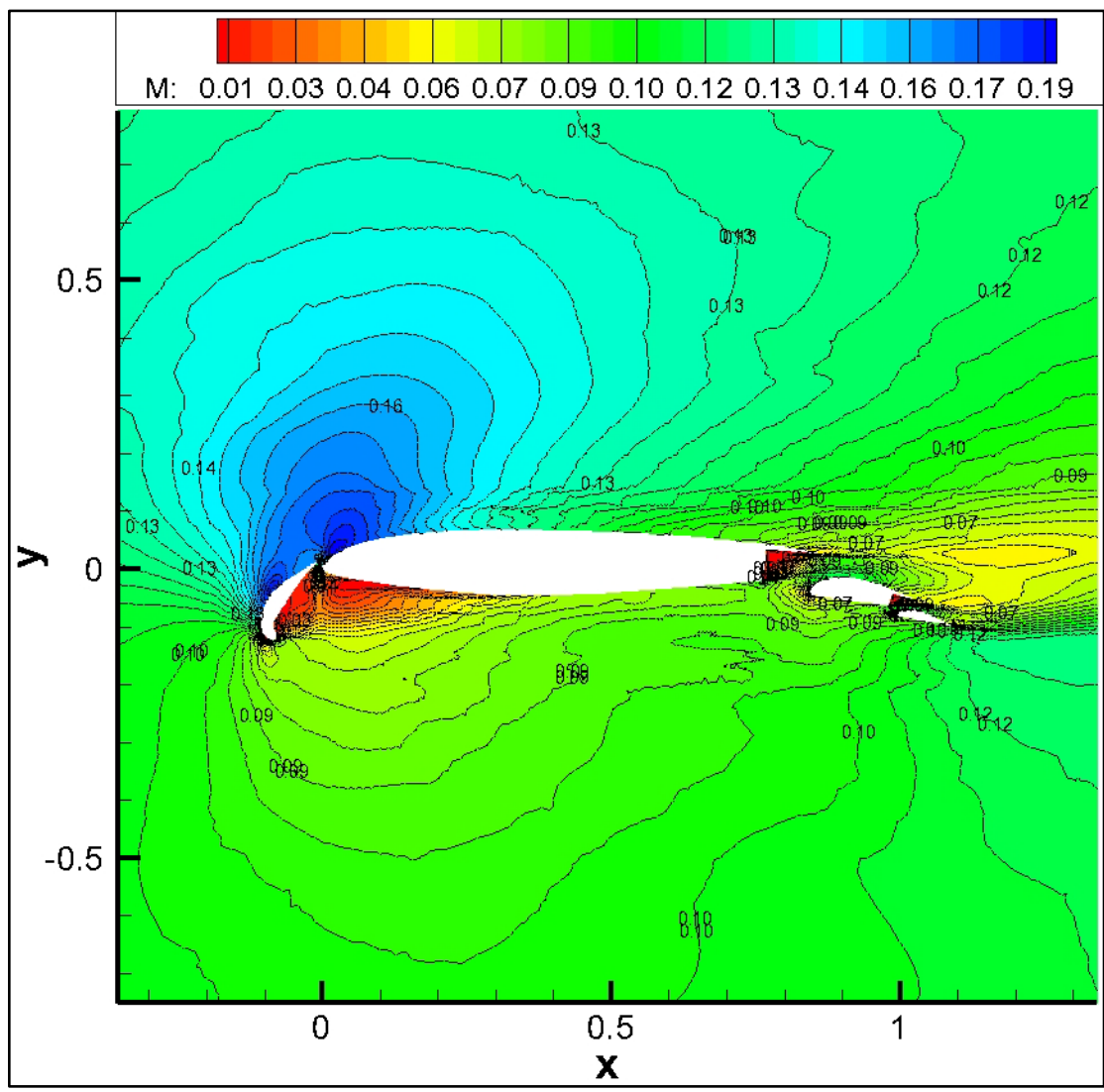

Figure 7. GeULER results of Mach number contours around BOEING Model TR-1332 by AUSM with two SR. 


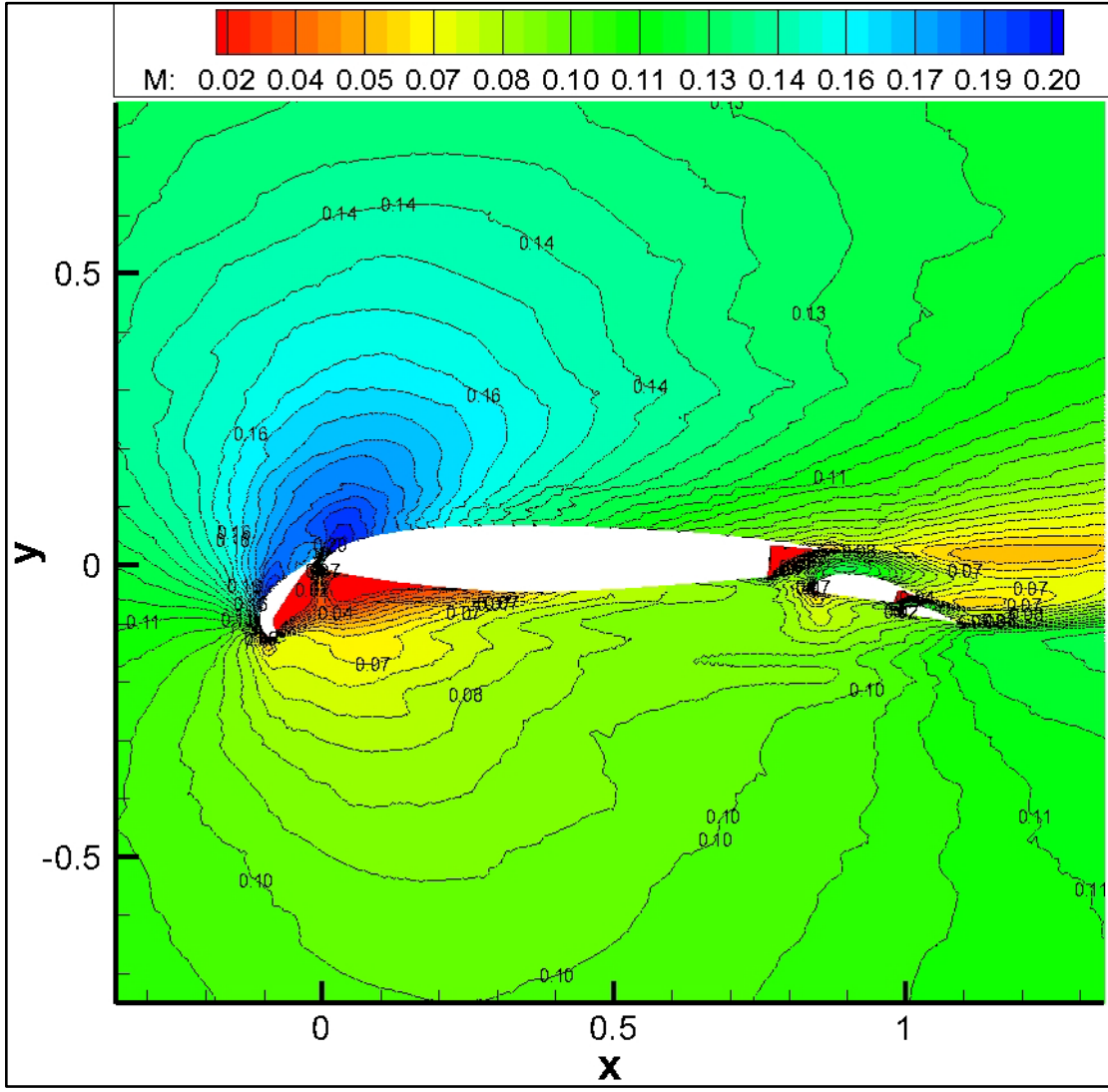

Figure 8. GeULER results of Mach number contours around BOEING Model TR-1332 by AUSM with three SR.

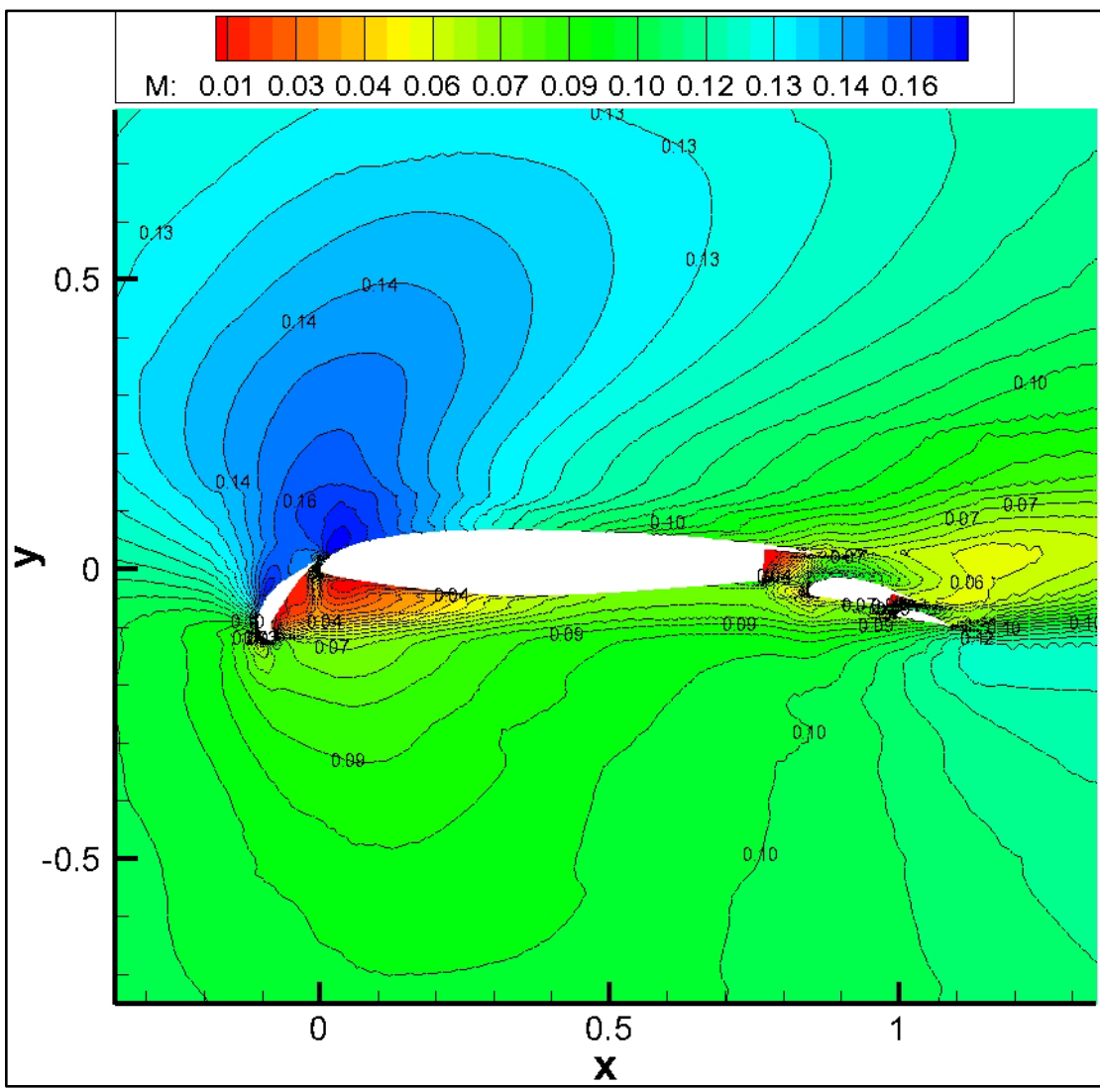

Figure 9. GeULER results of Mach number contours around BOEING Model TR-1332 by Roe’s Riemann solver with one SR 
Kara E., Kutlar Aİ., Aksel MH.

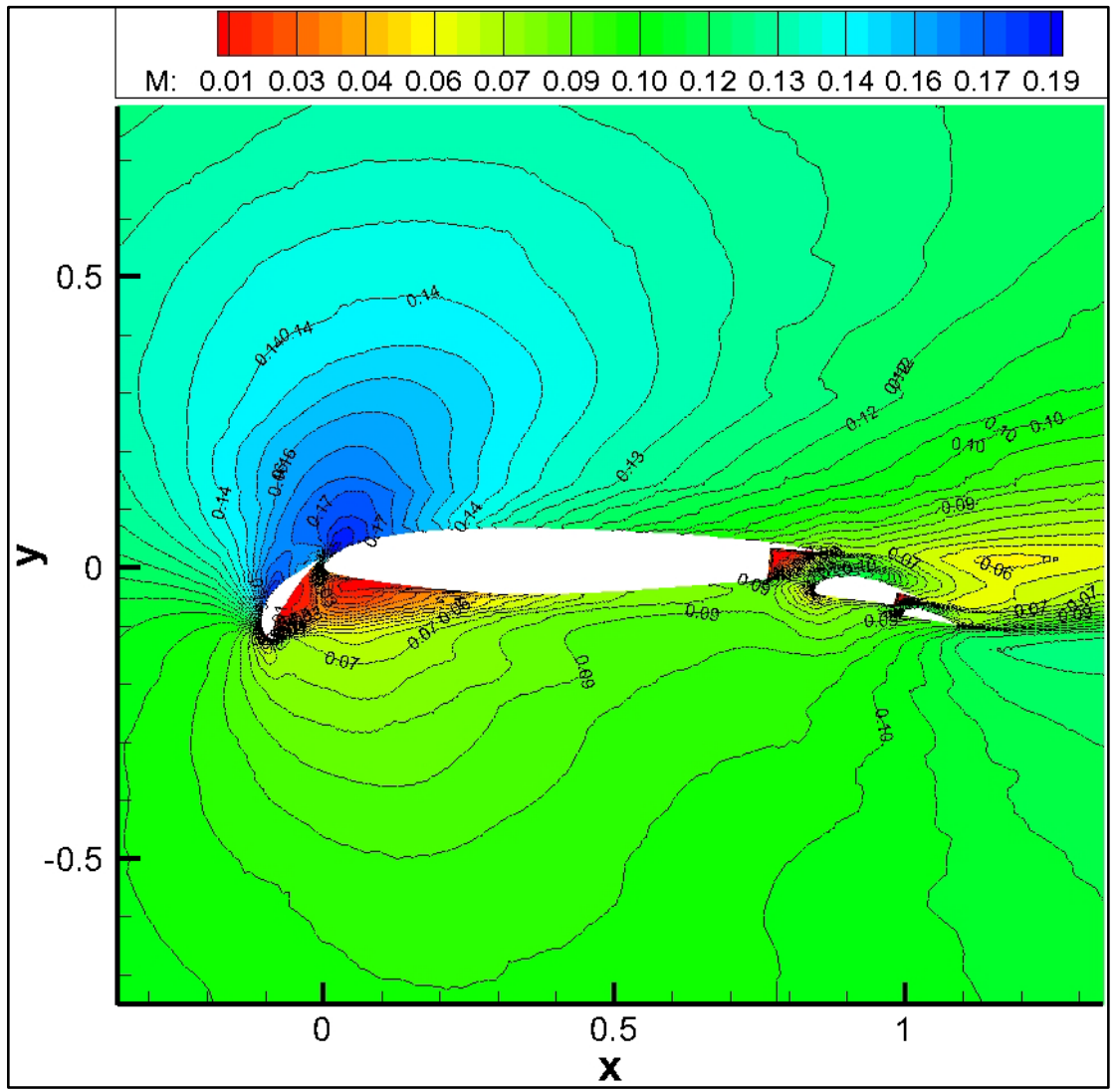

Figure 10. GeULER results of Mach number contours around BOEING Model TR-1332 by Roe’s Riemann solver with two SR.

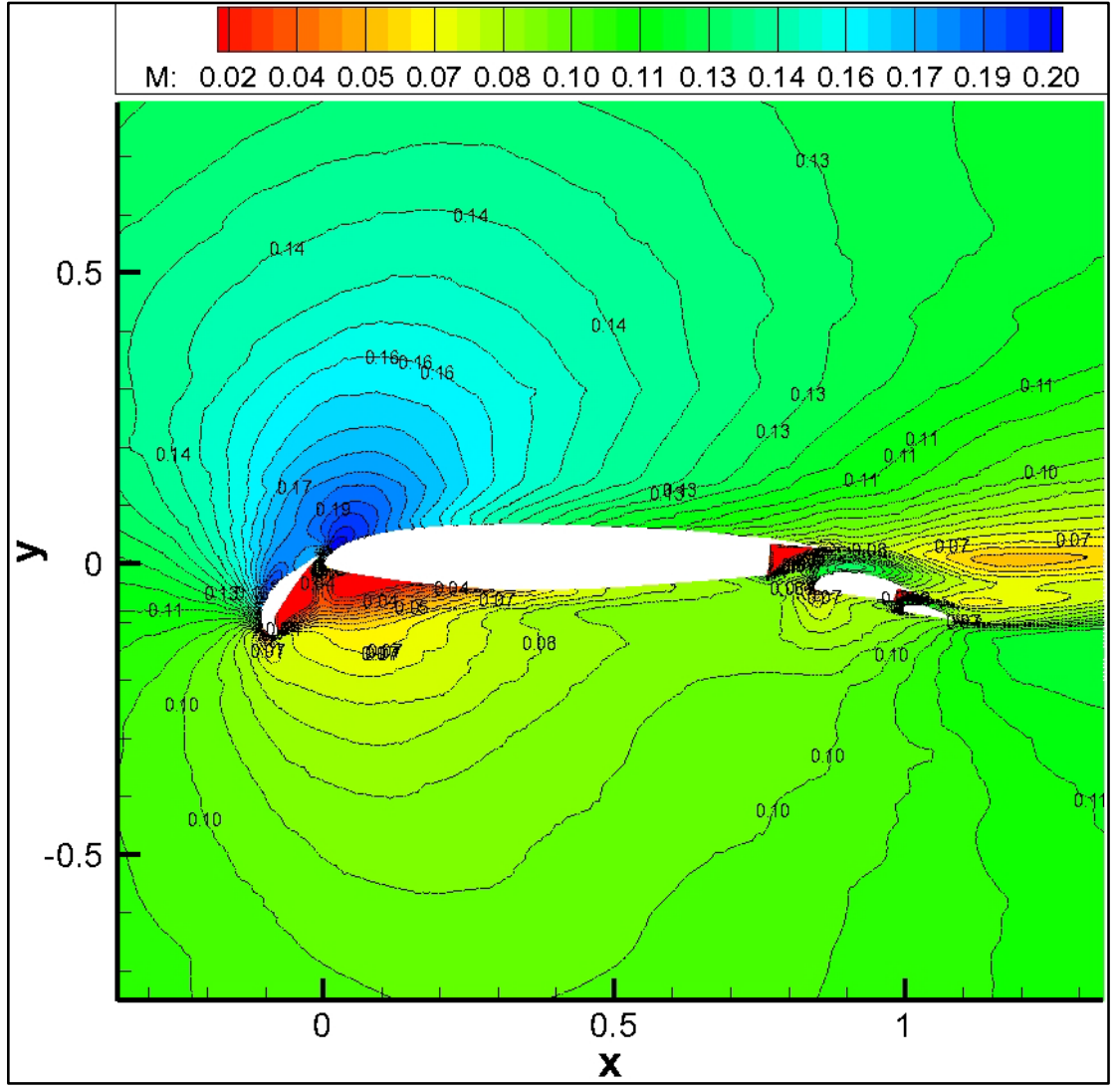

Figure 11. GeULER results of Mach number contours around BOEING Model TR-1332 by Roe’s Riemann solver with three SR. 
The difference between the pressure distribution of the experimental data and both solutions obtained over the slat is resulting because of the weak capture of confluent boundary layer between the slat and the main element of the airfoil [11]. Figures 6, 7 and 8 show the Mach contour distributions obtained from the AUSM solution scheme with one, two and three solution refinement levels around the BOEING Model TR-1332 airfoil, respectively. Figures 9, 10 and 11 show the Mach contour distributions obtained from the Roe's Riemann solution scheme with one, two and three solution refinement levels around the BOEING Model TR-1332 airfoil, respectively. It is seen that three solution refinement of Roe's Riemann solver gives the smoothest depiction among all.

\section{Discussion and Conclusion}

A subsonic flow at free stream Mach number of 0.11 around multi-element BOEING Model TR1332 airfoil is tested to predict pressure distributions around it and Mach contours of the flow are depicted by using the developed GeULER code with one, two and three solution refinement levels. Three solution refinements give the best pressure distribution results and smoothest depiction with respect to experimental data. The difference between the pressure distribution of the experimental data and solutions obtained over the airfoil is resulting partly because of the fact that the solver employs only inviscid terms of the governing flow equations (i.e. Euler Solver). Another reason for this difference is the singularity of the compressible flow based AUSM and Roe's Riemann solvers for the current nearly-incompressible flow test case. Although the Mach number is at the bound of incompressible flow, necessary observations are demonstrated. Firstly, the positive effect of the solution refinement increment on the accuracy of the solution schemes with respect to experimental data is clearly seen in Figure 4 and 5. Secondly, as Mach contours show through Figures 6 to 11, the flow decreases speed from $M=0.19$ to 0.11 over the upper surface while the flow increases speed from $\mathrm{M}=0.02$ to 0.10 over the lower surface. In other words, the speed of the flow on the upper surface is about ten times higher than the flow on the lower surface near the leading edge of the main airfoil. This high-lift behavior of the four-element airfoil is captured well with GeULER code. As a result, in current study an original GeULER mesh generator and flow solver program using object-oriented FORTRAN programming language is designed, coded and executed. Performance of the program is justified via a multi-element airfoil test case in two-dimensions and results are compared with experimental data. All results reveal the effectiveness of the program and suffice in accuracy and convergence.

\section{References}

[1] Marshall D. D., Ruffin S.M., “An embedded boundary Cartesian grid scheme for viscous flows using a new viscous wall boundary condition treatment" $42^{\text {nd }}$ AIAA Aerospace Sciences Meeting and Exhibit , 5-8 January, Reno, Nevada, USA, 2004.

[2] Wild J., "Experimental investigation of Mach- and Reynolds-number dependencies of the stall behavior of 2-element and 3-element high-lift wing sections" 50 $0^{\text {th }}$ AIAA Aerospace Sciences Meeting including the New Horizons Forum and Aerospace Exposition, 09-12 January, Nashville, Tennessee, USA, 2012. 
[3] Brune G.W., “A selection of experimental test cases for the validation of CFD codes: Twodimensional high-lift airfoil data for CFD code validation”, AGARD AR 303, NATO, New York, USA, 1-13, 1994.

[4] Kara E., Kutlar A.İ., Aksel M.H., "Quad-tree based geometric-adapted Cartesian grid generation" $8^{\text {th }}$ International WSEAS Conference on Continuum Mechanics, 16-19 July, Proceedings Book, 177 p, Rhodes Island, Greece, 15-19, 2013.

[5] Kara E., Kutlar A.İ., Aksel M.H., "A Quadtree based automatic adaptive Cartesian grid generator with applications on multi-element airfoils" $7^{\text {th }}$ Ankara International Aerospace Conference, 11-13 September, Abstract Book, 128 p, Ankara, 2013.

[6] Kara E, "Development of a Navier Stokes solver for compressible flows on Cartesian grids with aerodynamics applications", University of Gaziantep, Natural and Applied Sciences, Ph. D. thesis, 185 p, Gaziantep, 2015.

[7] Blazek J., “Computational fluid dynamics: Principles and applications” 2, Elsevier Ltd, 470 p, The Nederlands, 2005.

[8] Coirier W.J., Powell K.G., "A Cartesian, cell-based approach for adaptively-refined solutions of the Euler and Navier-Stokes equations” Surface Modeling, Grid Generation, and Related Issues in Computational Fluid Dynamic (CFD) Solutions, 9-11 May, 207-224, 1995.

[9] Çakmak M., "Development of a multi-grid accelerated Euler solver on adaptively refined two and three-dimensional Cartesian grids” Natural and Applied Sciences, Master thesis, 166 p, Ankara, 2009.

[10] Kidron Y., Mor-Yossef Y., Levy $\quad$ Y., “Turbulent flow predictions using a Cartesian flow solver” $19^{\text {th }}$ AIAA Computational Fluid Dynamics Conference, 22-25 June, San Antonio, Texas, USA, 2009.

[11] Mavriplis D.J. “Algebraic turbulence modeling for unstructured and adaptive meshes” AIAA Journal, 29.12, 2086-2093, 1991. 